10. Микієвич М. М., Яворська І. М. Правотлумачна діяльність суду Свропейського Союзу. Актуальні проблеми міжнародних відносин. 2013. Вип. 115(2). С. 17-22.

11. Право Европейского Союза. В 2 т. Т.2. Особенная часть: учебник для бакалавров / под. ред. С. Ю. Кашкина. 4-е узд., перерб. и доп. М.: Издательство Юрайт. 2013. 1023 с.

DOI https://doi.org/10.30525/978-9934-26-074-2-80

\title{
НАПРЯМИ ІМПЛЕМЕНТАЦІЇ ЄВРОПЕЙСЬКОГО ПРАВОВОГО РЕГУЛЮВАННЯ СКИДАННЯ РЕЧОВИН В УКРАЇНСЬКЕ ВОДНЕ ЗАКОНОДАВСТВО
}

\author{
Уберман В. I. \\ кандидат технічних наук, \\ провідний науковий співробітник лабораторії формування \\ та регулювання якості вод \\ Науково-дослідної установи «Украӥнський науково-дослідний інститут \\ екологічних проблем» \\ м. Харків, Украӥна \\ Васьковець Л. А. \\ кандидат біологічних наук, доцент, \\ професор кафедри безпеки прачі і навколишнього середовища \\ Національного технічного університету \\ «Харківський політехнічний інститут» \\ м. Харків, Украӥна
}

1. Лімітування надходження забруднюючих речовин (ЗР) у водні об’єкти України шляхом правого регулювання їх скидання (головним чином із зворотною водою точкових джерел) $\epsilon$ найбільш ефективним шляхом законодавчого забезпечення якості поверхневих вод. Сучасна українська система регулювання скидання ЗР (РСЗР) базується на застарілій та внутрішньо суперечливій постсоціалістичній екологоправовій концепції. Таке становище не змінилося навіть після формального переходу до європейського управління водними ресурсами за басейновим принципом, головні етапи якого виконано у 2019 р. Правові норми охорони поверхневих вод від забруднення та забезпечення їх якості зосереджено в підінституmax PCЗP еколого-правових 
комплексних інститутів якості води та їі регулювання екологічного законодавства СС та водного законодавства України [1] відповідно. Ядро підінституту РСЗР утворюеться законодавчими вимогами до обмеження скидання (або емісіі) у воду хімічних речовин (ХР), які надходять із точкових джерел, тобто лімітаційним регулюванням. Першочерговим завданням щодо імплементації європейського підінституту РСЗР у водне законодавство України слід вважати усунення поняттєво-категоріальних розбіжностей між українським підінститутом та його європейським відповідником. Загальна структура українського РСЗР встановлена у рамковому Законі України «Про охорону навколишнього природного середовища» (ЗУПОНПС), Водному кодексі України (ВКУ), низці підзаконних нормативно-правових актів. Спеціальні вимоги містяться у суміжних законодавствах: про охорону здоров'я, про рибне господарство та інших.

2. До головних особливостей еколого-правових концепцій українського РСЗР належать наступні. Об’єктом правового лімітування $\epsilon$ ЗР, які у ВКУ: 1) не мають чіткого фіксованого поділу за екологічними властивостями, поведінкою у воді та місцевими особливостями, окрім несистемних для РСЗР згадок про токсичні (ст. 71, 103), нафтові (ст. 100, 101), радіоактивні (ст. 36, 99, 102) та деякі ін. ХР; 2) поняття ЗР $\epsilon$ не абсолютним, а релятивним або умовним, тобто у загальному випадку будь-яка XР у зворотній воді не може бути наперед визнана як ЗР за іiі назвою або хімічною формулою без додаткових досліджень приймаючої води. У головному щодо РСЗР підзаконному акті [2, п. 4] використано поділ ЗР на основні, до яких належать 9 найбільш поширених у складі води речовин, та додаткові. Нормативними регуляторами у ВКУ $€$ нормативи гранично допустимого скидання ЗР (ГДС) (ст. 1,35), які характеризують склад зворотної води. Метою регулювання визначено поетапне «досягнення екологічного нормативу якості води» (ЕНЯВ) (ст. 36). Слід зазначити, що ЕНЯВ (ст. 37) є однозначним емпірикологічним конструктом, який інтегрує у своїй структурі «науково обгрунтовані значення концентрацій забруднюючих речовин та показники якості води у водних об’єктах (загальнофізичні, біологічні, хімічні, радіаційні)». Тобто у загальному випадку ЕНЯВ характеризує не одну, а багато $3 \boldsymbol{P}$ у приймаючій воді. Крім того, задекларована поетапність досягнення ЕНЯВ у ВКУ ніяк не визначається. ЕНЯВ не згадується серед екологічних нормативів у ст. 33 ЗУПОНПС. Авторами виявлено, що зазначена у ВКУ екологічна мета ГДС фактично змінюється чинними підзаконними актами і залишається господарською та санітарно-гігієнічною у практичній правозастосовній діяльності. Це викликано тим, що у [2, п. 3] неприпустимо викривлено мету 
встановлення ГДС: до ЕНЯВ додаються «санітарно-гігієнічні норми і правила ... «які у ВКУ належать до іншої категорії екологічних нормативів. Ще більшу плутанину викликає [3, п. 18], де до санітарногігієнічної мети ГДС додається вимога дотримання рибогосподарських нормативів без будь-якої згадки про ЕНЯВ. В акті [4] визначено, що до промислових ділянок рибогосподарських водних об'єктів (їх частин) належать майже усі масиви поверхневих вод України. Тим самим цільові ЕНЯВ фактично замінюються на рибогосподарські ГДК. Важливою особливістю виробничих установок скидання є властивість інженерної нерегульованості вмісту ЗР у зворотній воді переважної більшості з них, які давно побудовано та донині існують в Україні. При періодичному перегляді (переоформленні) нормативів ГДС ця технологічна особливість ізнорується. Крім того, за [3, п. 16] розрахункове визначення лімітів правового регулювання здійснюється у напрямі ЕНЯВ $\rightarrow$ ГДС, тобто нормативи ГДС є похідними.

3. За головним документом водної політики ЄС Директивою 2000/60/СС (ВРД) [5] європейський підінститут РСЗР характеризується наступними концептуальними особливостями та відмінностями від українського водного законодавства. У подальшому розгляді використовуються переклади, які найбільш відповідають українській науковій термінології та суспільній практиці. Об'єктами правового регулювання у ВРД є «забруднювачі», тобто хімічні речовини. Зміст цього поняття є абсолютним і відрізняється від ВКУ. Забруднювачі поділяються на «пріоритетні речовини» (зокрема, «небезпечні») (ПР) та «специфічні речовини» (СР). ПР регулюються за однаковими вимогами усіма державами-членами $\mathrm{CC}$, а $\mathrm{CP} є$ басейновими та локальними і можуть регулюватися за внутрішнім національним законодавством. До нормативних регуляторів у ВРД належать «засоби регулювання скидів» та «граничні значення викидів» (ГЗВ), друге з яких за формою збігається 3 ГДС. Кінцевою метою регулювання $\epsilon$ «добрий хімічний стан поверхневої води», а до складових цієї мети належить «стандарт якості довкілля» (СЯД), який за еколого-правовим змістом принципово відрізняється від нормативів екологічної безпеки водокористування у ВКУ. СЯД не має аналогів у ВКУ і $є$ суто екологічним нормативом для речовини або групи речовин, що визначає їх концентрацію, яка не має перевищуватися у воді, осадах чи біоті. На відміну від ВКУ у ВРД (ст. 10) визначено спосіб регулювання скидання: «Комбінований підхід» (КП), за яким європейське регулювання також принципово відрізняється від українського. За КП головним засобом лімітування ПР є обмеження їх емісії до ГЗВ, які відповідають «найкращим доступним технікам» (НДТ). Поняття НДТ та ГЗВ у ВКУ відсутні. Якщо задля досягнення визначеної цілі якості або 
СЯД таке обмеження виявиться недостатнім, то вимагаються більш жорсткі методи регулювання, зокрема, визначені у ст. 4 Directive 2008/105/EC (ДСЯД). Зокрема, при скиданні ПР за спеціальним переліком, надається можсливість використовувати властивості прилеглої до скиду частини масиву води, так званої зони змішування (33), для розбавлення концентрації речовини у викиді до рівня СЯД на межі поширення 33. У цьому випадку ГДВ є найбільшим значенням, яке після розбавлення скинутої ХР водою 33 забезпечує не перевищення СЯД поза 33. Наразі кількість ПР у переліку дорівнює 45, до яких додаються ще 8 речовин, що не належать до ПР і визначені іншими джерелами. Отже, 33 слід визнати важливим еколого-правовим засобом та інструментом підінституту РСЗР стосовно ПР.

Пропонуються зміни у ВКУ, які дозволять максимально наблизити український еколого-правовий підінститут РСЗР до його європейського відповідника. Першими кроками у напрямі зближення мають бути зміни поняттєвого-категоріального апарату ВКУ та виправлення деяких термінологічно некоректних перекладів ВРД, а першочергові нормативні вимоги мають стосуватися: 1) визначення переліків ПР та СР для українських річкових басейнів; 2) законодавчого запровадження системи національних СЯД; 3) законодавчого запровадження та нормативнодовідкового забезпечення КП; 4) розроблення та нормативно-довідкового супроводу системи НДТ; 5) створення вимог до визначення та встановлення 33.

\section{Література:}

1. Уберман В. I., Васьковець Л. А. Поетапне наближення українського еколого-правового інституту якості вод та ії регулювання до законодавства Свропейського Союзу. Chap. in book: Legislation of EU countries: history, shortcomings and prospects for the development : Collective monograph. Frankfurt (Oder) : Izdevniecība «Baltija Publishing», 2019. P. 334-354. URL: https://core.ac.uk/download/pdf/304678851.pdf . (дата звернення 27.03.2021).

2. Про затвердження Порядку розроблення нормативів гранично допустимого скидання забруднюючих речовин у водні об'єкти та перелік забруднюючих речовин, скидання яких у водні об'єкти нормується (затв. постановою Кабінету Міністрів України від 11 вересня 1996 р. № 1100 (в редакції Постанови КМ № 1091 (1091-2017-п) від 13.12.2017). URL: https://zakon.rada.gov.ua/laws/ show/1100-96-п . (дата звернення 27.03.2021).

3. Правила охорони поверхневих вод від забруднення зворотними водами (затв. постановою Кабінету Міністрів України від 25 березня 
1999 p. № 465). URL: https://zakon.rada.gov.ua/laws/show/465-99-п (дата звернення 27.03.2021).

4. Перелік промислових ділянок рибогосподарських водних об'єктів (ix частин). (затв. постановою Кабінету Міністрів України від 22 травня 1996 p.№ 552. URL: https://zakon.rada.gov.ua/laws/show/552-96-п (дата звернення: 27.03.2021).

5. Директива 2000/60/СС Європейського Парламенту і Ради «Про встановлення рамок діяльності Співтовариства в галузі водної політики» від 23 жовтня 2000 року. URL: https://zakon.rada.gov.ua/laws/show/ 994_962\#Text (дата звернення 27.03.2021).

6. Directive 2008/105/EC of the European Parliament and of the Council of 16 December 2008, on environmental quality standards in the field of water policy. URL: https://eur-lex.europa.eu/eli/dir/2008/105/oj (дата звернення 27.03.2021).

DOI https://doi.org/10.30525/978-9934-26-074-2-81

\title{
МІЖНАРОДНІ РЕГІОНАЛЬНІ МЕХАНІЗМИ ПРОТИДІЇ ТА БОРОТЬБИ З КОРУПЦЕЮ
}

\author{
Щерба В. Ю. \\ магістр права, \\ уповноважена з антикорупиійної діяльності \\ Державної установи «Територіальне медичне об'єднання \\ Міністерства внутрішніх справ Украӥни по Вінницькій області» \\ м. Вінниця, Украӥна
}

Міжнародна спільнота розглядає поняття «корупція» як комплексне, соціальне, економічне, політичне та культурне явище, яке справляє негативний вплив на всі сфери людського життя, у тому числі порушення основних прав людини та громадянина, спотворення демократичних процесів у державі, створення реальної загрози національній безпеці та перешкод для нормального розвитку демократичних країн світу.

В силу свого складного та комплексного характеру питання протидії та боротьби 3 корупцією регулюється нормативно-правовими актами міжнародного універсального, регіонального та національного рівнів. Акти універсального та регіонального рівнів, де визначені основні правила, механізми та принципи протидії та боротьби 3 корупцією, зазвичай містять у собі обов'язки або рекомендації для їх застосування державами у національних антикорупційних законодавствах. 